\title{
ANALISIS PELUANG PENERBITAN OBLIGASI DAERAH SEBAGAI ALTERNATIF PEMBIAYAAN DAERAH
}

\author{
Dewi Okta \\ Badan Perencanaan Pembangunan Daerah Pemerintah Provinsi Kalimantan Tengah \\ David Kaluge \\ Fakultas Ekonomi \& Bisnis Universitas Brawijaya
}

\begin{abstract}
Municipal bonds may be used as a source of regional funding.This study aims to analyze the feasibility of issuing municipal bonds as an alternative source of financing local infrastructure and analyze the strategies to be implemented by the government in the issuance of local bonds. Analysis tools used in this study were descriptive statistics and SWOT analysis. The analysis showed that municipal bonds are an alternative worth considering as a source of financing funding than other areas.
\end{abstract}

Keywords: municipal bonds, the financing area, the SWOT.

\section{A. LATAR BELAKANG}

Dalam pelaksanaan otonomi daerah, Pemerintah Daerah mempunyai hak dan kewajiban untuk mengatur dan mengurus urusan pemerintahannya, namun menemui keterbatasan dalam sumber pendanaan. Sebagian besar daerah kabupaten dan kota sangat bergantung pada dana perimbangan yang diberikan Pemerintah Pusat, baik itu Dana Bagi Hasil, DAU dan DAK. Sumber pemasukan lainnya yakni berasal dari Pendapatan Asli Daerah yang juga terbatas.

Hal ini di karenakan ketiga sumber pendanaan tersebut banyak terserap pada belanja rutin. Dengan kondisi keuangan tersebut tentunya sulit bagi pemerintah daerah untuk melaksanakan berbagai proyek pembangunan karena keterbatasan anggaran. Oleh sebab itu berbagai terobosan harus dilakukan oleh pemerintah daerah dalam upaya mencari sumber-sumber pembiayaan pembangunan demi tercapainya kesuksesan pelaksanaan otonomi daerah.

Adanya Undang-Undang Nomor 33 tahun 2004 yang menggantikan Undang-Undang Nomor 25 tahun 1999 tentang Perimbangan Keuangan antara Pemerintah Pusat dan Pemerintah Daerah memberikan sebuah peluang kepada pemerintah daerah untuk menggali dana (Fund Raising) dalam rangka pembangunan dan pengembangan daerah melalui penerbitan obligasi daerah seperti yang dituangkan dalam pasal 57 Undang-Undang tersebut yang lebih rinci mengatur obligasi daerah sebagai salah satu sumber pembiayaan daerah.

Obligasi daerah sebagai sumber dana, sudah lama dijadikan wacana dan bahan pembicaraan, baik di forum-forum formal baik didaerah maupun dipusat. Jika penerbitan obligasi daerah dapat direalisasikan, maka dalam struktur APBD obligasi daerah merupakan salah satu alternatif sumber pembiayaan dan tentunya dapat pula menjadi dukungan keuangan bagi pemerintah daerah.Secara 
resmi pemerintah daerah sudah dapat mempersiapkan penerbitan dan penjualan obligasi daerah ke masyarakat sejak ditetapkannya ketentuan itu dalam rapat Paripurna DPR yang mengesahkan amandemen pasal 51 UU Nomor 25 tahun 1999. Walaupun peraturan pemerintah yang mengatur tentang mekanisme penerbitan dan penjualan obligasi daerah baru diterbitkan tahun 2006.

Menyikapi peluang penerbitan obligasi daerah tersebut, beberapa Pemerintah Propinsi di Indonesia bahkan telah melakukan kajian persiapan untuk menerbitkan obligasi, diantaranya pemerintah Propinsi Riau, Jawa Tengah, Jawa Timur, Kalimantan Timur dan beberapa Pemerintah Propinsi lainnya. Untuk Pemerintah Propinsi sudah seharusnya melakukan kajian yang sama tentang kemungkinan penerbitan obligasi daerah sebagai salah satu sumber pembiayaan pembangunan. Kajian ini menjadi sangat urgen, karena pada pasal 59 ayat 1 Undang-Undang Nomor 33 tahun 2004 diatur bahwa pemerintah pusat tidak menjamin obligasi daerah, sehingga jika Pemerintah daerah ingin menggunakan instrumen obligasi sebagai sumber pembiayaan, maka harus benar-benar memperhatikan aspek kemampuan keuangan dan manajemen keuangan pemerintah daerah

Untuk menjawab pertanyaan apakah pemerintah daerah layak untuk menerbitkan obligasi daerah, maka diperlukan suatu kajian yang hasilnya perlu dipertimbangkan sebagai dasar kebijakan bagi Pemerintah daerah dalam menerbitkan obligasi daerah. Sehingga tujuan dari penelitian ini adalah 1). Menganalisi kelayakan obligasi daerah sebagai sumber dana pembangunan di daerah; 2). Mengidentifikasi peluang dan potensi pemerintah daerah dalam penerbitan obligasi daerah; dan 3). Menganalisis strategi-strategi yang perlu ditempuh pemerintah dalam rangka penerbitan obligasi daerah.

\section{B. KAJIAN TEORITIS}

\section{Dasar Hukum}

Keterbatasan sumber pembiayaan dalam negeri yang berasal dari pemerintah pusat, dihadapkan pada semakin meningkatnya kebutuhan pembiayaan pembangunan daerah. Memberikan peluang bagi pemerintah daerah untuk mencari alternatif sumber-sumber untuk memperoleh hutang jangka panjang dari luar negeri dan sumber hutang dalam negeri non pemerintah. Salah satu sumber pembiayaan pembangunan daerah setelah keluarnya UndangUndang Nomor 25 tahun 1999 tentang perimbangan keuangan antara pemerintah pusat dan pemerintah daerah adalah berkaitan dengan penerbitan obligasi daerah. Adapun dasar hukum diperbolehkannya penerbitan obligasi daerah antara lain :

1. Undang-undang Nomor 17 Tahun 2003 tentang Keuangan Negara;

2. Undang-undang Nomor 33 Tahun 2004 tentang Perimbangan Keuangan antara Pemerintah Pusat dan Pemerintahan Daerah;

3. $\quad$ Undang-undang Nomor 8 Tahun 1995 tentang Pasar Modal;

4. Peraturan Pemerintah Nomor 23 Tahun 2003 tentang Pengendalian Jumlah Kumulatif Defisit APBN dan APBD serta Jumlah Kumulatif Pinjaman Pemerintah Pusat dan Daerah;

5. Peraturan Pemerintah Nomor 54 tahun 2005 tentang Pinjaman Daerah; 


\section{Peraturan Pemerintah Nomor 58 tahun 2005 tentang Pengelolaan Keuangan Daerah.}

\section{Definisi Obligasi Daerah}

Definisi obligasi daerah sesuai Peraturan Menteri Keuangan Nomor147/PMK.07/2006 tentang Tata Cara Penerbitan, Pertanggungjawaban, dan Publikasi Informasi Obligasi Daerah, maka pengertian obligasi daerah adalah Pinjaman Daerah yang ditawarkan kepada publik melalui penawaran umum di pasar modal.Pengertian tersebut sesuai dengan pengertian obligasi daerah dalam Peraturan Pemerintah nomor 54 tahun 2005 tentang pinjaman daerah.

Obligasi Daerah merupakan surat utang yang diterbitkan oleh pemerintah daerah yang ditawarkan kepada publik melalui penawaran umum di pasar modal. Obligasi ini tidak dijamin oleh Pemerintah Pusat (Pemerintah) sehingga segala resiko yang timbul sebagai akibat dari penerbitan Obligasi Daerah menjadi tanggung jawab Pemerintah Daerah. Penerbitan suratutang merupakan bukti bahwa pemerintah daerah telah melakukan pinjaman/utang kepada pemegang surat utang tersebut. Pinjaman akan dibayar kembali sesuai dengan jangka waktu dan persyaratan yang disepakati. Pemerintah daerah yang menerbitkan obligasi daerah berkewajiban membayar bunga secara berkala sesuai dengan jangka waktu yang telah ditetapkan.Pada saat jatuh tempo pemerintah daerah berkewajiban mengembalikan pokok pinjaman.

Tujuan dari penerbitan Obligasi Daerah adalah untuk membiayai suatu kegiatan investasi sektor publik yang menghasilkan penerimaan dan memberikan manfaat bagi masyarakat.Untuk itu perlu diperhatikan bahwa penerbitan obligasi tidak ditujukan untuk menutup kekurangan kas daerah.Obligasi Daerah akan diperjualbelikan di pasar modal dalam negeri sesuai dengan peraturan perundang-undangan pasar modal.

\section{Karakteristik Obligasi Daerah}

Peraturan Pemerintah Nomor 54 Tahun 2005 tentang Pinjaman Daerah, mengamanatkan bahwa obligasi daerah yang diterbitkan hanya jenis obligasi pendapatan (revenue bonds).Kegiatan yang didanai melalui penerbitan obligasi daerah harus menghasilkan penerimaan, namun tidak harus mencapai pemulihan biaya penuh (full cost recovery). Peraturan yang sama juga mengamanatkan bahwa apabila kegiatan belum menghasilkan dana yang cukup untuk membayar pokok, bunga, dan denda maka pembayaran dilakukan dari APBD.

Secara khusus, Obligasi Daerah memiliki karakteristik sebagai berikut:

1. merupakan pinjaman jangka panjang yang berasal dari masyarakat (lebih dari satu tahun sesuai dengan syarat perjanjian pinjaman yang bersangkutan). Obligasi di Indonesia umumnya mempunyai jangka waktu sekitar 5 tahun atau lebih;

2. diterbitkan melalui penawaran umum kepada masyarakat di pasar modal dalam negeri;

3. dikeluarkan dalam mata uang rupiah;

4. hasil penjualan digunakan untuk membiayai investasi sektor publik yang menghasilkan penerimaan dan memberikan manfaat bagi masyarakat; dan

5. nilai obligasi daerah pada saat jatuh tempo sama dengan nilai nominal obligasi daerah pada saat diterbitkan. 


\section{Jenis Obligasi Daerah}

Menurut Sunariyah(2004), jenis kontrak perjanjian (bond indenture) antara pembeli dan penjual obligasi menentukan jenis obligasi yaitu :

1. Collateral

Perusahaan penerbit obligasi apabila menjamin sejumlah aset milik perusahaan untuk menutup pembayaran jatuh tempo obligasi.

2. Debenture

Perusahaan penerbit obligasi apabila tidak menjamin dengan sejumlah aset tertentu, akan tetapi dijamin dengan tingkat kwalitas perusahaan.

3. Subordinate Debenture

Perusahaan penerbit obligasi menentukan siapa yang terlebih dahulu prioritas dibayar apabila perusahaan bangkrut. Subordinate debenture dibayar setelah debenture.

4. Obligasi Pendapatan (Income Bonds)

Obligasi jenis ini, tidak dijamin dengan aset tertentu, tidak mempunyai kewajiban bunga secara periodik membayar bunga apabila mencapai laba yang cukup dan tidak ada utang lainnya, apabila periode yang lalu tidak mampu membayar.

Secara umum obligasi daerah dapat diarahkan pada dua jenis sebagaimana dikemukakan Subiyanto H. (2004) :

1. General Obligation Bonds

General obligation bonds adalah obligasi yang dikeluarkan untuk membiayai pelayanan publik yang tidak dapat diharapkan pembayarannya, melalui fee pada pemakaiannya dan dibayar kembali dengan pajak dan sumber dana lain (jalan umum, sekolah, bangunan publik)

2. Revenue Bonds

Revenue Bonds adalah obligasi yang dikeluarkan untuk proyek-proyek yang menghasilkan pendapatan kemudian hari dan menjadi sumber pembayaran kembali hutang tersebut melalui retribusi pada pemakaiannya (jalan tol, listrik, air minum, sanitasi, pelabuhan)

Sedangkan menurut Purwoko (2005), berdasarkan sifat atau perilakunya serta tujuan penggunaan dana yang dihasilkan, obligasi daerah dapat dibedakan menjadi :

a. General Obligation Bond merupakan obligasi yang diterbitkan oleh pemerintah daerah dalam rangka memperoleh dana untuk pembiayaan umum daerah, baik untuk pengeluaran rutin maupun untuk proyek-proyek sarana umum yang dibangun oleh pemerintah daerah, misalnya pembangunan jalan, jembatan, tanggul pengendali banjir, dan fasilitas lain yang tidak mendatangkan penghasilan. Kupon dan pengembalian general obligation bond sepenuhnya menjadi beban APBD.

b. Special Revenue Bond merupakan obligasi yang diterbitkan secara khusus untuk membiayai pembangunan proyek-proyek yang menghasilkan pendapatan, sehingga pembayaran kupon dan pelunasan obligasi ini akan dibayar dari penghasilan proyek yang didanai. Contoh special revenue bond adalah pembangunan jalan tol, atau pembangunan kawasan pariwisata. Kedua proyek ini dapat menghasilkan pendapatan yang bisa digunakan untuk membayar kupon dan melunasi obligasi. 
c. Limited Tax Bond merupakan obligasi yang digunakan untuk membangun proyek tertentu, misalnya pusat prebelanjaan, dimana untuk membayar kupon dan Sebagai mengembalikan pokok pinjaman obligasi ini dibackup dengan pajak yang dipungut dari kawasan pusat perbelanjaan tersebut.

d. Double Barrel Bond merupakan obligasi yang diperlukan untuk membiayai proyek-proyek dalam jumlah besar. Karena besarnya jumlah pinjaman, pengembalian obligasi ini perlu dibackup dua lapis. Misalnya obligasi yang diterbitkan dalam rangka pembangunan jalan tol. Selain menggunakan pendapatan dari jalan tol, pelunasan obligasi jenis ini juga dibayar dari penghasilan pajak kendaraan sebagai backup lapis kedua. Apabila backup lapis kedua dirasa kurang, bisa ditambah dengan back up lapis ketiga, dan seterusnya.

e. Incremental Tax Bond, hasil penjualan obligasi jenis ini digunakan untuk membiayai proyekproyek yang secara langsung tidak menghasilkan penghasilan, namun secara tidak langsung dapat memberikan tambahan pendapatan bagi pemerintah daerah. Tambahan pendapatan ini yang digunakan untuk membayar kupon dan melunasi incremental tax bond.

f. Special Assessment Bond, digunakan untuk membiayai infrastruktur yang dibangun untuk dinikmati oleh sebagian masyarakat saja, misalnya untuk membangun jaringan gas untuk masyarakat perkotaan. Penerima manfaat dari proyek ini hanyalah penduduk yang tinggal di wilayah perkotaan. Oleh karenanya, hanya masyarakat perkotaan yang berlangganan gas saja yang seharusnya bertanggung jawab terhadap pembayaran kupon dan pelunasan obligasi.

g. Private Activity Bond, obligasi yang dijamin oleh pemerintah daerah yang bertujuan tidak untuk mencari laba. Sebagai contoh, obligasi yang diterbitkan untuk pembangunan rumah sakit atau sekolah swasta.

\section{Kegiatan yang Dapat Dibiayai Obligasi Daerah}

Pemerintah Daerah dapat menerbitkan Obligasi Daerah hanya untuk membiayai kegiataninvestasi sektor publik yang menghasilkan penerimaan dan memberikan manfaat bagi masyarakat yang menjadi urusan Pemerintah Daerah berdasarkan peraturan perundangan yang berlaku.Obligasi yang diterbitkan dapat digunakan untuk membiayai beberapa kegiatan yang berbeda.

Kegiatan pemerintah daerah yang dapat dibiayai dengan obligasi daerah di antaranya:

a. pelayanan air minum;

b. penanganan limbah dan persampahan;

c. transportasi;

d. rumah sakit;

e. pasar tradisional;

f. tempat perbelanjaan;

g. pusat hiburan;

h. wilayah wisata dan pelestarian alam;

i. terminal dan sub terminal;

j. perumahan dan rumah susun;

k. pelabuhan lokal dan regional. 


\section{Pihak-Pihak yang Terkait Dengan Obligasi Daerah}

Pihak-pihak yang terlibat dengan obligasi daerah adalah sebagai berikut:

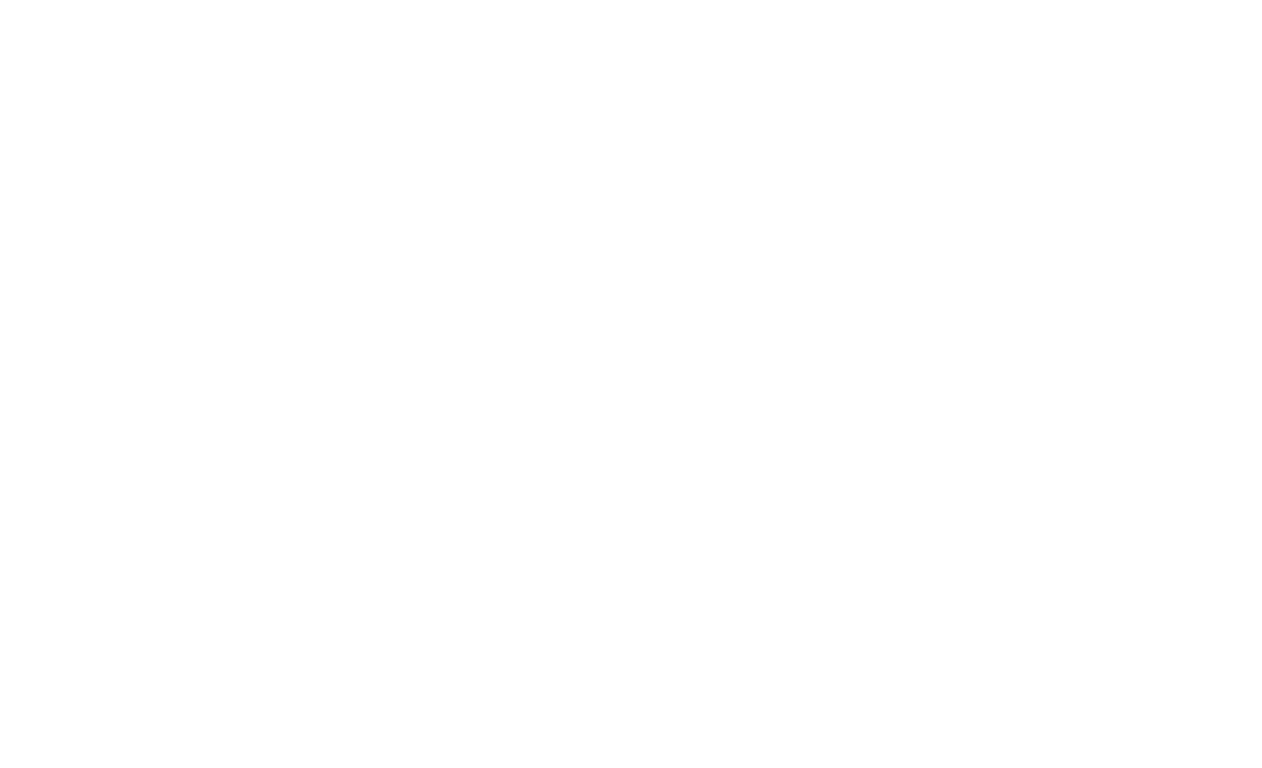

Gambar 1. Pihak-pihak yang terlibat dengan obligasi daerah

1. Regulator, adalah lembaga/instansi pemerintah yang memiliki kewenangan untuk mengatur dan mengawasi pelaksanaan penawaran umum obligasi daerah di pasar modal. Pengawasan tersebut merupakan tanggung jawab Departemen Keuangan dimana secara prakteknya dilakukan oleh Badan Pengawas Pasar Modal-Lembaga Keuangan, dan Direktorat Jenderal Perimbangan Keuangan.

a. Direktorat Jenderal Perimbangan Keuangan (DJPK), merupakan unsur di dalam Departemen Keuangan, yang bertindak atas nama Menteri Keuangan untuk mengevaluasi dan memberikan persetujuan atas rencana penerbitan obligasi daerah yang diajukan oleh pemerintah daerah serta mengawasi pengelolaan obligasi daerah, sesuai dengan kerangka kerja pinjaman daerah seperti diatur dalam PP 54/2005.

b. Bapepam Lembaga Keuangan (Bapepam-LK), adalah Badan Pengawas Pasar Modal dan Lembaga Keuangan yang bertugas untuk melakukan pembinaan, pengaturan dan pengawasan Pasar Modal dengan tujuan mewujudkan terciptanya kegiatan Pasar Modal yang teratur, wajar, dan efisien serta melindungi kepentingan pemodal dan masyarakat.

2. Self Regulatory Organizations (SRO), merupakan lembaga/organisasi yang berwenang untuk mengeluarkan peraturan bagi kegiatan usahanya. Di pasar modal, SRO terdiri dari bursa efek, lembaga kliring dan penjaminan, serta lembaga penyimpanan dan penyelesaian.

a. Bursa Efek, adalah pihak yang menyelenggarakan dan menyediakan system dan atau sarana untuk mempertemukan penawaran jual dan beli efek pihak-pihak lain dengan tujuan memperdagangkan efek di antara mereka. 
b. Lembaga Kliring dan Penjaminan, adalah pihak yang menyelenggarakan jasa kliring dan penjaminan penyelesaian transaksi bursa. Di Indonesia, lembaga kliring dan penjaminan yang telah mendapat izin dari Bapepam LK adalah PT. Kliring Penjaminan Efek Indonesia (PT. KPEI).

c. Lembaga Penyimpanan dan Penyelesaian, adalah pihak yang menyelenggarakan kegiatan kustodian sentral bagi bank kustodian, perusahaan efek, dan pihak lain. Di Indonesia, lembaga penyimpanan dan penyelesaian yang telah mendapat izin dari Bapepam dan LK adalah PT. Kustodian Sentral Efek Indonesia (PT. KSEI).

3. Emiten, merupakan pihak yang melakukan penawaran umum. Dalam kaitannya dengan obligasi daerah, pihak yang menjadi emiten adalah pemerintah daerah.

4. Pemegang Efek, adalah investor atau pihak yang menanamkan modalnya dalam bentuk pemberian pinjaman kepada pemerintah daerah dalam bentuk obligasi daerah.

5. Perusahaan Efek, adalah perusahaan yang mempunyai aktivitas sebagai penjamin emisi efek, perantara pedagang efek, manajer investasi, atau gabungan dari ketiga kegiatan tersebut.

a. Penjamin Emisi Efek, adalah pihak yang membuat kontrak dengan emitenuntuk melakukan penawaran umum bagi kepentingan emiten dengan atau tanpa kewajiban untuk membeli sisa efek yang tidak terjual.

b. Perantara Pedagang Efek, adalah pihak yang melakukan kegiatan usaha jual beli efek untuk kepentingan sendiri atau pihak lain.

c. Manajer Investasi, adalah pihak yang kegiatan usahanya mengelola portofolio efek untuk para nasabah atau mengelola portofolio investasi kolektif untuk sekelompok nasabah, kecuali perusahaan asuransi, dana pensiun dan bank yang melakukan sendiri kegiatan usahanya berdasarkan peraturan perundang-undangan yang berlaku.

6. Lembaga Penunjang, merupakan pihak-pihak penunjang terlaksananya pelaksanaan penawaran umum, yang terdiri dari biro administrasi efek, kustodian dan wali amanat.

a. Biro Administrasi Efek, adalah pihak yang berdasarkan kontrak dengan emiten melaksanakan pencatatan pemilikan efek dan pembagian hak yang berkaitan dengan efek.

b. Kustodian, adalah pihak yang memberikan jasa penitipan efek dan harta lain berkaitan dengan efek serta jasa lain, termasuk menerima deviden, bunga, dan hak lain, menyelesaikan transaksi efek, dan mewakili pemegang rekening yang menjadi nasabahnya.

c. Wali Amanat, adalah pihak yang mewakili kepentingan pemegang efek bersifat utang (termasuk obligasi daerah). Penunjukan Wali Amanat dilakukan melalui perjanjian bersama seluruh pihak pada penerbitan obligasi daerah. Wali amanat bertugas untuk mengendalikan seluruh aspek-aspek administratif penerbitan obligasi daerah, termasuk memastikan bahwa penerbitan obligasi daerah telah sesuai dengan ketentuan dan persyaratan pada perjanjian obligasi daerah.

7. Profesi Penunjang, merupakan pihak-pihak yang karena profesinya, turut menunjang terlaksananya penawaran umum di pasar modal. Untuk melakukan kegiatan di bidang pasar modal, profesi penunjang pasar modal wajib terlebih dahulu terdaftar di Bapepam dan LK. Profesi penunjang terdiri dari akuntan publik, notaris, konsultan hukum dan perusahaan penilai. 
8. Pihak Lain Yang Terlibat, merupakan pihak-pihak lain yang juga terlibat dalam pelaksanaan penawaran umum obligasi daerah di pasar modal, namun tidak terlibat secara langsung dalam proses transaksi perdagangan efek, yang terdiri dari penyedia penguatan kredit, lembaga pemeringkat efek serta penasihat investasi.

a. Lembaga Pemeringkat Efek, merupakan lembaga yang memberikan peringkat kredit bagi penerbit obligasi daerah. Lembaga pemeringkat mengukur kelayakan kredit, kemampuan membayar pinjaman yang akanmempengaruhi tingkat bunga pinjaman.

b. Penyedia Penguatan Kredit, adalah pihak yang memberikan penguatan kredit melalui pernyataan kesediaan menjamin obligasi daerah, dimana penguatan kredit ini akan memberikan kenyamanan bagi investor dan dapat mempengaruhi tingkat bunga.

c. Penasihat Investasi, merupakan pihak yang memberikan nasihat kepada pihak lain berkaitan dengan penjualan atau pembelian efek dengan memperoleh imbalan jasa.

\section{Proses Persiapan Penerbitan Obligasi Daerah}

Sebelum obligasi daerah diterbitkan di pasar modal, terdapat beberapa tahap yang harusdilakukan oleh pemerintah daerah terlebih dahulu.Tahap-tahap tersebut meliputi persiapan di daerah, persetujuan Menteri Keuangan, tahap pra-registrasi dan registrasi, hingga tahap penawaran umum. Tahapan ini merupakan langkah-langkah yang harus ditempuh secara berurutan sesuai dengan Peraturan Menteri Keuangan Nomor 147/PMK.07/2006 dan peraturan-peraturan Bapepam dan LK sebagaimana akan dijelaskan dalam Bab IV Buku Panduan ini.

Secara umum, proses persiapan penerbitan obligasi daerah dilakukan dengan alur sebagaiberikut:

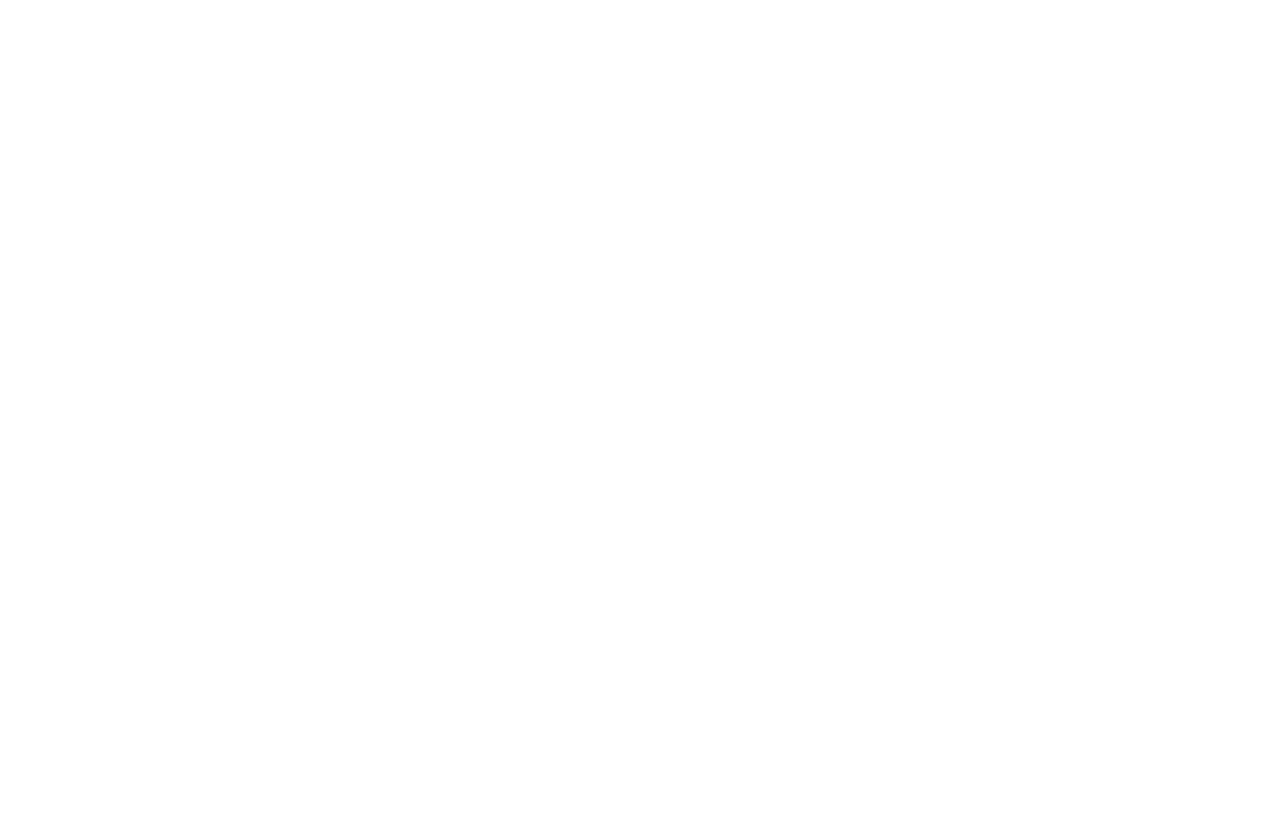

Gambar 2. proses persiapan penerbitan obligasi daerah 
Tahap persiapan dapat dilakukan dengan alur seperti digambarkan dalam bagan berikut:

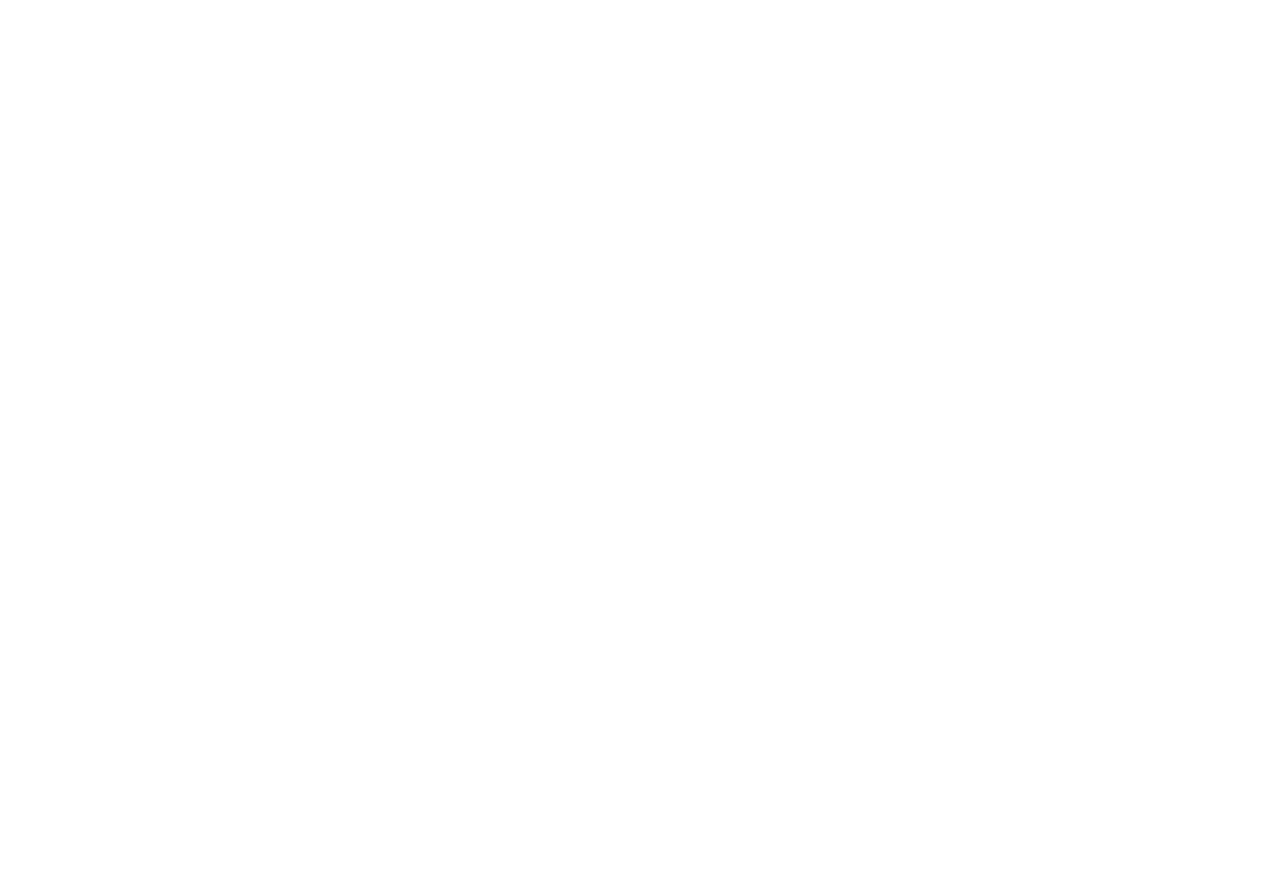

Gambar 3. Tahap Persiapan Penelitian Obligasi Daerah

\section{Manfaat Berinvestasi Pada Obligasi Daerah}

Penerbitan obligasi daerah pada nominal yang terjangkau oleh masyarakatumum akan memberikan manfaat kepada pemerintah memperoleh dana yang bersumber dari "Idle money" yang ada pada masyarakat dan secara tidak langsung mengikut sertakan masyarakat untuk berpartisipasi dalam proses pembangunan. Tingkat manfaat bagi masyarakat berinvestasi pada obligasi daerah sebagaimana pada obligasi umumnya :

1. Kupon

Kupon adalah besarnya biaya yang dibayarkan secara regular yang dinyatakan dalam persentase terhadap nilai nominal obligasi daerah. Misalnya tingkat kupon $12 \%$, artinya setiap tahun jumlah bunga yang dibayarkan kepada pemegang obligasi sebesar $12 \%$ dikalikan besarnya nominal (Rp. 500.000) $=$ Rp. 60.000.

2. Capital gain

Capital gain adalah selisih antara harga jual dengan harga beli obligasi daerah.Jika harga jual lebih tinggi dari pada harga beli maka investor memperoleh capital gain, sebaliknya investor bisa-bisa capital loss, apabila harga jual obligasi lebih rendah dibandingkan dengan harga beli.Jika nominal obligasi daerah Rp. 500.000 dan dibeli dengan harga pasar Rp. 475.000, makacapital loss adalah Rp. 25.000 (Rp. 500.000 - Rp. 475.000). 
3. Resiko yang kecil

Hal yang membedakan obligasi daerah dengan sekuritas lainnya adalah padasangat kecilnya bahkan hampir tidak adanya resiko gagal bayar baik kuponmaupun pokok obligasi daerah.Jika membeli obligasi korporasi/swasta atau sekuritas lainnya, ada kemungkinan terjadinya gagal bayar kupon maupun pokok yang jatuh tempo akibat kondisi keuangan atau bisnis yang tidak menguntungkan. Obligasi daerah merupakan sekuritas yang bebas resiko gagal bayar, karena daerah di anggaran pemerintah pada APBD. Sesuai dengan Undang-Undang No. 33 tahun 2004.

4. Sebagai Jaminan

Obligasi daerah dapat dijadikan sebagai agunan dan dapat dijual setiap saatapabila pemegang obligasi membutuhkan dana, dengan menjualnya kepasar.

5. Partisipasi dalam Pembangunan

Dengan adanya obligasi daerah yang nominalnya dapat terjangkau olehmasyarakat umum, investasi masyarakat pada obligasi daerah merupakan wujud nyata partisipasi masyarakat dalam proses pembangunan.

\section{METODE PENELITIAN DAN ANALISIS DATA}

Data yang digunakan dalam penelitian ini adalah data sekunder, yaitu dari buku-buku, artikel, jurnal, serta homepage yang berkaitan dengan obligasi daerah. Analisis dilakukan dengan menggunakan statistik deskriptif dan analisis SWOT. Statistik deskriptif digunakan untuk analisis komparasi dari berbagai alternatif pembiayaan pembangunan daerah, untuk melihat sejauhmana kelayakan obligasi daerah sebagai sumber dana pembangunan di daerah, dibandingkan dengan alternatif pembiayaan lainnya. Analisis SWOT digunakan untuk mengkaji peluang, ancaman, kelebihan, dan kekurangan penerbitan obligasi daerah sebagai sumber dana pembangunan daerah, serta menentukan strategi-strategi yang perlu ditempuh oleh pemerintah dalam rangka penerbitan obligasi daerah.

\section{HASIL DAN PEMBAHASAN}

\section{Analisis Perbandingan Sumber Pembiayaan Di Daerah}

Berdasarkan karakteristik dari sumber-sumber pembiayaan, dapat dibuat analisis perbandingan dalam bentuk matrik sebagai berikut: 
Tabel 1. Matrik Perbandingan Karakteristik Pembiayaan

\begin{tabular}{|c|c|c|c|c|}
\hline $\begin{array}{l}\text { Berdasarkan } \\
\text { Sumber } \\
\text { Pembiayaan } \\
\text { Variabel }\end{array}$ & $\begin{array}{c}\text { Kredit } \\
\text { Investasi }\end{array}$ & $\begin{array}{l}\text { Development } \\
\text { Sharing }\end{array}$ & BOT & $\begin{array}{l}\text { Obligasi } \\
\text { Daerah }\end{array}$ \\
\hline $\begin{array}{l}\text { Kemampuan } \\
\text { menyediakan dana }\end{array}$ & Sedang & Sedang & Sedang & Tinggi \\
\hline $\begin{array}{l}\text { Biaya untuk } \\
\text { memperoleh dana }\end{array}$ & Sedang & Rendah & Rendah & Rendah \\
\hline Tingkat bunga & Tinggi & Rendah & Rendah & Tinggi \\
\hline $\begin{array}{l}\text { Risiko terhadap } \\
\text { perubahan kurs }\end{array}$ & Tinggi & Rendah & Rendah & Rendah \\
\hline $\begin{array}{l}\text { Risiko terhadap } \\
\text { perubahan kebijakan } \\
\text { Pemerintah }\end{array}$ & Tinggi & Sedang & Sedang & Rendah \\
\hline $\begin{array}{l}\text { Hak penguasaan } \\
\text { investor terhadap } \\
\text { infrastruktur }\end{array}$ & Rendah & Tinggi & Tinggi & Rendah \\
\hline $\begin{array}{l}\text { Minat investor } \\
\text { terhadap } \\
\text { pembiayaan } \\
\text { infrastruktur }\end{array}$ & Rendah & Sedang & Sedang & Tinggi \\
\hline
\end{tabular}

Perbankan dapat menyediakan dana yang cukup memadai untuk pembangunan infrastruktur, namun mengingat waktu pengembalian yang panjang menyebabkan minat perbankan untuk membiayai infrastruktur menjadi rendah. Development sharing dan BOT melibatkan pihak swasta yang diharapkan tertarik untuk berinvestasi infrastruktur daerah. Namun sayangnya tidak banyak pihak swasta yang memiliki cukup dana dan berkeinginan untuk membangun infrastruktur. Pembiayaan infrastruktur melalui penerbitan obligasi mampu menyediakan dana dalam jumlah besar, karena melibatkan banyak pihak. Pembiayaan ini memiliki risiko terhadap perubahan kurs rendah, karena tingkat bunga dapat di tetapkan pada saat penerbitan obligasi. Kebijakan pemerintah tidak mudah mempengaruhi pola pembiayaan dengan obligasi, karena sudah diatur dalam kontrak. Apabila likuiditas obligasi dapat dilaksanakan dengan baik dan tingkat bunga yang lebih kompetitif dibandingkan dengan bunga deposito, minat pemilik dana untuk memiliki obligasi akan semakin besar, sehingga obligasi merupakan alternatif yang baik sebagai sumber pembiayaan dalam rangka pembangunan daerah.

\section{Kendala Penerbitan Obligasi Daerah}

Kendala proses penerbitan obligasi daerah terutama menyangkut peraturan administrasi, institusi dan keberadaan kwalitas sumber daya manusia yangmenangani obligasi tersebut. Kewenangan pemerintah daerah dalam mengelola pinjaman telah diaturdengan Undang-Undang No. 33 tahun 2004, namun Undang-Undang atauperaturan yang melibatkan instansi tertentu dalam penerbitan obligasi daerahtersebut belum diatur seperti : peraturan-peraturan (PP) BAPEPAM belummengatur tentang obligasi daerah (yang diperkirakan tahun 2005 telah diterbitkan). Kepmen keuangan tentang obligasi daerah bank Indonesia dan Departemen Dalam Negeri. 
Undang-undang atau peraturan tertentu merupakan acuan kegiatan proses penerbitan obligasi daerah yang harus ada sebagai dasar hukum proses penerbitan obligasi daerah.Peraturan Bapepam yang mengatur obligasi daerah menentukanpemerintah daerah dalam menerbitkan obligasi daerah harus menerapkan suatukondisi atau syarat yang mana pemerintah daerah belum memiliki atau belummenerapkan kondisi syarat tersebut pada kegiatan pengelolaan pemerintah daerah.

Banyak faktor yang terlebih dahulu dibenahi untuk proses penerbitan obligasi:

1. Penerapan Standar Akuntansi Keuangan Pemerintah Daerah

2. Debt Management Unit (DMU) Obligasi Daerah

3. SDM Pengelolaan DMU

4. Pengetahuan masyarakat tentang seluk beluk obligasi daerah

5. Menentukan lembaga Rating Agincy (RA)

6. Lembaga Penjamin

Hambatan yang utama penerbitan obligasi daerah adalah belum lengkap Peraturan Pemerintah (PP) dan Peraturan Pemerintah Daerah (Perda) sehingga tidak mungkin dalam waktu dekat ini untuk melakukan penerbitan obligasi daerah.Laporan Keuangan Pemerintah Daerah yang memuat neraca laba rugi, laporan surplus defisit dan laporan realisasi anggaran, belum menganut standar Akuntansi Keuangan Pemerintah, perlu diperlakuan dengan sistem yang dianjurkan Bapepam, yang merupakan salah satu syarat suatu institusi dalam penerbitan obligasi.

Penerapan standar Akuntansi Keuangan.Pemerintah Daerah perlu disiapkan agar persyaratan yang diterbitkan Bapepam dapat dipenuhi.Kegiatan NNpengelolaan dan administrasi penyelenggaraan pemerintah sudah padat di tambah lagi dengan pengelolaan dan administrasi kegiatan obligasi daerah, tidak memungkinkan secara administrasi, untuk itu perlu di bentuk suatu badan yang khusus mengelola kegiatan penerbitan obligasi daerah.(Debt Management Unit Obligasi Daerah). Pengelolaan utang yang disebabkan penerbitan obligasi tidak perlu ditangani bagian anggaran, akan tetapi ditangani oleh Debt Management Unit (DMU).

DMU mempunyai tugas menyusun level utang, merencanakan kebutuhan biaya, mengkaji alternatif pembayaran pokok dan bunga, dan menyiapkan administrasi penerbitan obligasi daerah.Badan yang mengelola utang (obligasi) diperlukan kwalifikasi sumber dayamanusia (SDM) yang mempunyai kwalifikasi professional tertentu danberpengalaman. Untuk itu mendudukkan SDM tertentu pada DMU perlu direkrut dari instansi dilingkungan pemerintah atau dari instansi lain dan melakukanpendidikan terhadap SDM. Keberadaan kualifikasi SDM yang professional pada DMU sangat urgen dalam menjalankan fungsi DMU yang berhubungan denganobligasi daerah. Persiapan SDM yang berkwalitas perlu dilakukan pemerintahdaerah dalam melakukan persiapan proses penerbitan obligasi daerah.

Kebijakan yang ditempuh oleh pemerintah daerah sehubungan denganpenerbitan obligasi daerah, perlu dipahami oleh masyarakat untuk merespon yang positif. Pengetahuan masyarakat tentang seluk beluk obligasi daerah perlu ada agar kebijakan yang ditempuh pemerintah dalam pembiayaan pembangunanmelalui penerbitan obligasi mendapat respon yang positif maupun koreksi dansaran sehubungan dengan penerbitan obligasi tersebut. Tanpa memahami selukbeluk 
penerbitan obligasi daerah, bagaimana bisa melakukan respon, koreksi dansaran terhadap kebijakan penerbitan obligasi dalam pembiayaan pembangunan daerah.

Pemerintah dalam persiapan penerbitan obligasi, perlu menentukan suatu lembaga peringkat (Rating Agincy) yang independent menentukan peringkat atasobligasi yang akan diterbitkan. Misalnya obligasi BEI II tahun 2005 ini mendapatperingkat BBB + dari PT. Pefindo. (Media Indonesia 30-3-2005). Moody'smenggunakan area untuk rating tertinggi, diikuti Aa, A, Baa, Ba, $\mathrm{Caa}, \mathrm{Ca}, \mathrm{C}$ dan $\mathrm{D}$ untuk rating terendah. Peringkat ini menggambarkan keberadaan resiko yang dihadapi obligasi daerah, yang dinilai dari kapasitas ekonomi, dan hukum terkaitsehubungan dengan kapasitas ekonomi, dan hukum terkait dengan penerbitanobligasi daerah (standard and Poor's di AS).

Semakin tinggi obligasi, semakin rendah resiko yang dihadapi investor semakin rendah rating obligasi semakin tinggi resiko yang dihadapi. Pemerintahdaerah harus dapat menentukan lembaga peringkat untuk persiapan menentukanobligasi yang akan diterbitkan. Masa berlakunya obligasi daerah ditentukan pada perjanjian antaraPemerintah Daerah yang menerbitkan obligasi daerah dengan wali amanat yangmewakili investor.Namun peran penting sehubungan dengan sukses atau tidaknya penerbitan obligasi daerah dijamin oleh lembaga penjamin (underwriting).Lembaga penjamin dapat berfungsi membantu emiten dalam pendaftaran obligasidibursa efek.Persiapan underwriten sangat diperlukan dalam memenuhi ketentuanperaturan Bapepam.

\section{Analisis Obligasi Daerah Sebagai Alternatif Pembiayaan di Daerah}

Analisis ini dimaksudkan untuk melihat lebih dalam tentang apa kelebihan, kelemahan, peluang serta ancaman dari penerbitan obligasi daerah sebagai sumber pembiayaan pembangunan di daerah, serta strategi apa yang perlu diterapkan agar penerbitan obligasi daerah dalam rangka pembiayaan pembangunan daerah dapat berjalan dengan baik. Berikut hasil dari analisis SWOT:

Tabel 2. Analisis SWOT penerbitan obligasi daerah sebagai alternatif pembiayaan pembangunan daerah

\begin{tabular}{l}
\hline STRENGTH \\
\hline - Semangat membangun daerah \\
- Masyarakat memiliki potensi untuk \\
membeli obligasi daerah \\
- Jaringan perbankan telah menjangkau \\
daerah-daerah, berpotensi sebagai outlet \\
untuk melayani penjualan dan pembelian \\
obligasi daerah
\end{tabular}

OPPORTUNITY

- Undang-undang Keuangan Negara memberikan peluang kepada daerah untuk memperoleh pinjaman, antara lain dalam bentuk obligasi daerah
- Pengalaman default obligasi negara

- Pengalaman default obligasi korporasi

- Masa jabatan kepala daerah dan DPRD hanya 5 tahun

- Nilai nominal obligasi yang beredar saat ini terlalu tinggi untuk dapat dijangkau oleh masyarakat

\section{THREAT}

- Penerbitan obligasi daerah akan meningkatkan volume utang pemerintah, yang dapat mengakibatkan meningkatnya country risk 

- Proyek Pembangunan yang dibiayai dengan penerbitan obligasi daerah berpeluang untuk mempercepat pertumbuhan ekonomi daerah
- Bunga obligasi dinikmati oleh masyarakat (pembeli obligasi) setempat, sehingga dapat meningkatkan perputaran perekonomian daerah
- Penerbitan obligasi daerah dapat menimbulkan moral hazard bagi pejabat daerah, dengan cara menikmati hasil pinjaman dan memberikan beban utang kepada generasi berikutnya
- Penerbitan obligasi daerah dapat mempertajam kesenjangan antar daerah

\section{Sumber: http://www.fiskal.depkeu.go.id/webbkf/kajian\%5Cpurwoko-1.pdf}

Berdasarkan analisis kekuatan, kelemahan, peluang, dan ancaman di atas, maka strategi yang seyogyanya ditempuh dalam rangka penerbitan obligasi daerah sebagai alternatif pembiayaan daerah adalah sebagai berikut:

a. Strategi Memanfaatkan Kekuatan Untuk Menangkap Peluang

Memanfaatkan semangat membangun yang dimiliki masyarakat daerah serta potensi masyarakat untuk berpartisipasi membangun daerah, melalui penerbitan obligasi daerah.

b. Strategi Memanfaatkan Kekuatan Untuk Mengeliminasi Ancaman

- Memanfaatkan semangat membangun yang dimiliki masyarakat daerah untuk meringankan beban APBD dalam rangka pembangunan daerah

- Mengikutsertakan masyarakat dalam mekanisme pengawasan proyek pembangunan infrastruktur dalam rangka meminimize kemungkinan terjadinya moral hazard oleh pejabat daerah

c. Strategi Memperbaiki Kelemahan Untuk Menangkap Peluang

- Perlu segera dibuat aturan/aspek legal dari penerbitan obligasi daerah

- Perlu disiapkan infrastruktur dan outlet untuk melayani penjualan dan pembelian obligasi daerah

- Agar dapat dijangkau oleh masyarakat daerah, penerbitan obligasi daerah dibuat dalam bentuk retail/nilai nominal kecil

d. Strategi Memperbaiki Kelemahan Untuk Mengeliminasi Ancaman

- Untuk memperkecil kemungkinan terjadinya moral hazard, obligasi daerah seyogyanya tidak diterbitkan oleh Pemerintah Daerah, tetapi oleh Badan otorita Daerah atau BUMD. Pemerintah Daerah lebih tepat berfungsi sebagai badan pengawas, sedangkan pelaksanaan pembangunan dan pengelolaan infrastruktur atau aset daerah dilakukan oleh Badan Otorita Daerah atau BUMD

- Pembayaran kupon dan pelunasan Obligasi sepenuhnya menjadi tanggung jawab Penerbit Obligasi, sehingga tidak membebani APBD 


\section{E. KESIMPULAN}

\section{Kesimpulan}

Obligasi daerah merupakan alternatif yang layak dipertimbangkan sebagai sumber pembiayaan daerah dibandingkan pendanaan yang lain. Kelebihan obligasi daerah sebagai alternatif pendanaan pembangunan, antara lain mampu menarik minat pemilik dana untuk berinvestasi, mampu menyediakan dana dalam jumlah besar, memiliki risiko yang rendah atas perubahan kurs, memiliki risiko yang rendah atas perubahan kebijakan pemerintah.

Beberapa strategi dapat ditempuh oleh pemerintah daerah dalam rangka penerbitan obligasi daerah antara lain memanfaatkan semangat membangun yang dimiliki masyarakat daerah serta potensi masyarakat daerah untuk pembangunan daerah melalui penerbitan obligasi daerah, mengikutsertakan masyarakat dalam mekanisme pengawasan proyek dalam rangka meminimize kemungkinan terjadinya moral hazard oleh pejabat daerah, perlu segera dibuat aturan/aspek legal dari penerbitan obligasi daerah, perlu disiapkan infrastruktur dan outlet untuk melayani penjualan dan pembelian obligasi daerah, penerbitan obligasi daerah dibuat dalam bentuk retail/ nilai nominal kecil agar dapat dijangkau oleh masyarakat daerah, penerbitan obligasi daerah oleh Badan Otorita Daerah atau BUMD dan pembayaran kupon dan pelunasan obligasi sepenuhnya menjadi tanggung jawab Penerbit Obligasi, sehingga tidak membebani APBD.

\section{DAFTAR PUSTAKA}

Direktorat Jenderal Perimbangan Keuangan Departemen Keuangan, 2007 Paduan Penerbitan Obligasi Daerah

Direktur Jenderal Perimbangan Keuangan Departemen Keuangan RI, 2006. Pengenalan Dan Pemahaman Penerbitan Obligasi Daerah.

Peraturan Menteri Keuangan Nomor 147, 2006. Tatacara Penerbitan, Pertanggungjawaban, dan Publikasi Informasi Obligasi Daerah

Koesno, "Obligasi Daerah, Potensi Penghimpunan Dana Bagi Pembangunan Daerah dan Alternatif Investasi I Pasar Modal', Makalah diseminarkan di Jakarta, tahun 2001.

Purwoko, “Analisis Peluang Penerbitan Obligasi Daerah Sebagai Alternatif Pembiayaan Infrastruktur Daerah”, http://www.fiskal.depkeu.go.id/webbkf/kajian\%5Cpurwoko-1.pdf, akses 1 April 2011.

Peraturan Pemerintah No. 107 tahun 2000 tentang Pinjaman Daerah.

Undang-undang No. 25 tahun 1999 tentang Perimbangan Keuangan antara Pemerintah Pusat dan Daerah. 